\title{
'Elective affinities': interdiscursive dynamics between football, the economy and nationalism in Germany
}

\section{Clara Ervedosa}

To cite this article: Clara Ervedosa (2018): 'Elective affinities': interdiscursive dynamics between football, the economy and nationalism in Germany, National Identities, DOI: 10.1080/14608944.2018.1530647

To link to this article: https://doi.org/10.1080/14608944.2018.1530647

曲 Published online: 16 Nov 2018.

Submit your article to this journal $₫$

Џ Article views: 11

View Crossmark data $־$ 


\section{'Elective affinities': interdiscursive dynamics between football, the economy and nationalism in Germany}

\section{Clara Ervedosa}

Centre for Social Studies (CES), University of Coimbra, Coimbra, Portugal

\begin{abstract}
After WWII, nationalism in Germany was frowned upon as a phenomenon of the extreme right. For the critical voices at the end of the sixties and in the seventies, national identity meant more than ever to constantly ask oneself what it meant to be German. However, almost thirty years after reunification, nationalist tendencies have quickly reached the midst of society. The article argues that nationalism did not manifest itself in political or cultural discourses due to post-war taboos, but rather in surrogate ones, especially in football and the economy. Perceived as 'neutral fields' in contrast to politics, they paved the way to the 'normalisation' of national feelings and the gradual redefinition of the German post-war identity - an identity largely based on a narrative of competition, success, and 'German virtues'.
\end{abstract}

\section{KEYWORDS}

Football; economy; German nationalism; interdiscursive dynamics

\section{Nationalism and football as surrogate discourses. Introduction}

Nationalism is on the rise in Europe and beyond, as political developments in France, England, Poland, Austria and the US have shown. Although its decline had been prophesied in the EU context (Wehler, 2001, pp. 104-115) and in the era of globalisation (Held, 1990; Hobsbawm, 1990, p. 182), it is not in sight. In fact, Benedict Anderson's verdict in 2006: '[...] nation-ness is the most universally legitimate value in the political life of our times' (Anderson, 2006, p. 3) has not forfeited its validity.

Comparatively, nationalist tendencies in post-war Germany seemed for a long time to be non-existent. After WWII and the 'rupture in civilisation' of the Holocaust (Diner, Claussen, \& Brumlik, 1988), nationalism had been long considered a phenomenon of the extreme right and was frowned upon. For the critical voices at the end of the sixties and in the seventies, national identity meant more than ever to constantly ask oneself what it meant to be German.

In order to overcome the stigma of the Third Reich and gain acceptance among the other nations, Germany assumed a modest, self-contained attitude in the international arena. Politics concentrated mainly on pragmatic issues and assumed a sober managerial-functional style, while taking a reserved stance towards open nationalism and national symbolism, which even became taboo. 
However, almost thirty years after reunification, nationalist tendencies have reached the midst of society (Heitmeyer, 2006). ${ }^{1}$ The fact that the new right-wing party Alternative für Deutschland $(A f D)$, which had been initially founded as a protest party against the Euro in 2013, shifted its focus away from the European single currency to refugees and immigration, and was rewarded by the electorate with the third strongest result of all parties during the 2017 general election, is a further indication of this. ${ }^{2}$ Since then, the latent, reserved nationalism of the post-war era has been reinforced by open, self-assertive and vociferous altero-referential discourse in the sense of Colette Guillaumin (1995, p. 51 ), i.e. mainly defined openly in opposition to the 'other', ${ }^{3}$ including Germans with a 'migration background'. 4

In light of this, questions arise about the quick renaissance of nationalism in a country with a lacerated national identity, one where intellectuals discussed in the 90 s whether the Holocaust was the basis of national identity. ${ }^{5} \mathrm{~A}$ country in which public figures, such as the journalist Dolf Sternberger and the philosopher Jürgen Habermas, argued that postnational 'constitutional patriotism' ${ }^{6}$ should become the legitimating pillar of the German state (Sternberger, $1990^{2}$; Von Beyme, 1999, p. 49). How could nationalism, the stigmatising of entire religions and minorities, ${ }^{7}$ including attacks on memory politics, achieve such widespread success within such a short period of time, given the legacy of the German past?

This article argues that nationalism as emotional identification with one's own country (Gellner, 1991, p. 8) did not emerge out of nowhere. Rather, there were already latent but burgeoning forms, mainly after reunification and before the formation of the AfD. Yet, due to the post-war taboos surrounding this topic, traces of it should not be sought mainly in political or cultural discourses but rather in surrogate ones, especially in football and the economy. In contrast to politics, they were perceived as 'neutral fields', in which Germans could feel like a collective and, particularly with respect to football, show their emotions, including those towards their country (Daalmann, 1998, pp. 30, 39). They contributed to break the taboo over the course of time and paved the way to the 'normalisation' of national feelings among those who had either been immune to such sentiment due the recent German past or sparked a revival of such nationalist feelings among those who had repressed but did not dare to voice them. Besides, they helped the gradual redefinition and expression - subtle or more direct - of the German national narrative in the post-war period.

This article does not intend to draw a causal line from football and the economy to the AfD, though. That would be too simplistic a notion that does not do justice to those subsystems. It argues, rather, that football and the economy created a terrain which can be easily capitalised and hijacked by other parties such as the AfD. By contributing to 'normalisation' and articulation of a nationalism based on a narrative of competition and success, instead of an humanist one - as the journalist Cordt Schnibben observed, the postwar nation does not see itself primarily as a 'Kulturnation' with its icons Bach, Goethe, and Schiller, but rather the German Mark, Mercedes, AEG and Krupp (Schnibben, 1993, p. 108 ) , it created a narrative that can be easily mobilised towards a self-assertive, aggressive and all-enveloping ethnic-biological nationalism as defended by the AfD - especially at a time in which the economy has been losing its social integrating power. As the historian Hans-Ulrich Wehler pointedly highlighted out only four years after reunification, the ideal of the Volksnation, the ethnical nation, can quickly pose a social threat by becoming an 
easy and 'cheap' symbolic binding element for an anxious, divided society in lieu of the idea of a 'nations of citizens' based on a constitution and a welfare state, as well as the liberal-democratic political culture of the GFR (Wehler, 1994, pp. 778, 786, 788).

\section{Terminological and methodological considerations}

Language and discourses play a constitutive role in nationalism, the political ideology that confers the sense of unity to a nation. Even if, in most cases, the nation presupposes political institutions and structures, it is language, along with symbols, and a collective narrative, that add the necessary all involving framing and sense of belonging to the ideology an unity that sometimes does not even exist on an institutional, pragmatic level. When nationalism becomes a taboo in politics, as it happened in the German case after World War II, open manifestations of it tend to be avoided. However, this does not mean that the ideology and ideas behind it evaporate. This article argues that German nationalism rather expressed itself 'between the lines', especially in subsystems that become important to a society.

As is known, complex societies are divided in subsystems such as politics, economy, justice, sports etc. with their respective institutions, main actors, rules, values, language and discourses. In comparison to other subsystems, football and the economy grew in relevance after World War II and particularly after reunification in Germany. According to Alexander Ziem, football even became a Leitdiskurs, that is, not only an increasingly independent and professionalised field of action with its own discourse, but also an extremely popular and influential one, whose traces can be found in other social subsystems both on the pragmatic and on the discursive level (Ziem, 2010a). Football is not only a game on the grass, but also a knowledge form that influences our daily action and thinking (Ziem, 2010b, p. 231). The heated discussion that took place after the conclusion of this article over Mesut Özil's photograph with Recep Tayyp Erdoğan in 2018 and over his refusal to continue to play for the German national team after it was knocked out of World Cup 2018 , illustrates how football can operate as a surrogate discourse for politically repressed issues. In this particular case, it reignited a debate over dual citizenship and what is German identity in a diverse society.

It is similarly unquestioned that the economy, the subsystem that has to do with money, pecuniary transactions, and finance, has also assumed a central and quasi-religious relevance. This can be seen in the power of economists, banks, rating agencies, or as reflected in spectacular architecture in the finest city quarters. The market economy's competitive, utilitarian, profit-oriented logic has also permeated almost all areas of our lives, including personal relations (Sennett, 1998).

In functionally differentiated societies, there is not only the tendency towards the formation of relatively independent subsystems and to knowledge specialisation, but also a contrary propensity to mixing and reintegrating of different discourse streams, as the Germanist Jürgen Link stated, as Ziem confirmed regarding football. Whereas specialised discourse and knowledge production - the one Foucault dealt mostly with - takes place in academia, interdiscourse happens mostly in representations in the media, in literature, in talk shows, etc and aims at transmitting knowledge to a larger group of recipients (Link, 2011, p. 435). Therefore, interdiscurse between economy, football, and nationalism, as we defend here, is basically the result of linguistic interactive relations between 
discursive elements and formations, meaning that aspects of one discourse and one subsystem can easily be imported into the other discourses on different area and other subsystems. We would like to add that this propensity to interdiscursive mingling tends to be stronger and more subtle if a topic or an area is made taboo, as nationalism used to be in Germany, and therefore seeks a surrogate existence in other areas.

Interdiscourse analysis as we intend to carry out in this article thus focuses on the decoding and interpreting of discourse complexes that are not clearly limited by certain fields of academic expertise, but that encompass more comprehensive areas and different sources and how they are represented in different media. Besides, it does not intend to be an empirical sociological analysis of real institutions and social structures, but rather an interpretative, interdisciplinary work in the area of German Studies. It aims mainly at finding linguistic and discursive elements that establish relations and construct similarities between these diversified sets of knowledge such as analogies, similar narrative schemes, metaphorical vocabulary, collective symbols etc. This approach is not tantamount to the elimination of material references or the denial of the power of social institutions, structures and events, though. In fact, such references e.g. the economic miracle, the Marshall plan, the reunification, the Agenda 2010, etc. will be continuously mentioned in the article. It rather means that the focus will be on language and discourses as these can develop their own dynamics and even lead an independent existence. Even though they do not necessarily mirror those material references, they constitute a reaction to them in one way or the other. They can even be an attempt to hide, distort or even deny them, as is the case of nationalism that does not reflect the diversity of the German postwar society, but rather produces an idea of unity that does not encompass all social groups and contradicts the growing inequality within German society.

In order to get to grips with the complexity of an interdiscursive approach, the focus in this article will be put on the interpretation of three central interdiscursive formations - the 'elective affinities', so to speak - between the economy, football and nationalism, namely the relevance of inclusion and exclusion mechanisms, the rhetoric of competition and success, and of the German virtues. As the next section will show in more detail, they do not only play a central and pivotal function between these fields, but also disclose the narrative that supports nationalism.

Despite the retrospective perspective and manifold historical dates in the present work, it does not aim at reconstructing historically how central episodes related to football and the economy really occurred, nor analyse past relevant debates on German national identity and nationalism. For instance, with regards to the so-called 'economic miracle', it is not decisive whether it was really a 'miracle' or a specific German phenomenon, but that it was, and still is, represented and perceived as such and what their gives away about nationalism.

Similarly, to say that football and economy were considered to be 'neutral' does not mean that they were in fact neutral. What is said is rather that they were represented and perceived as unproblematic or even technocratic in contrast to other areas. Whereas nationalism would have been sanctioned if pursued openly in the political sphere because the German nation was under observation after World War II, this would not be the case if it happened in the areas of the economy and football. 'Representation' in this context bears the idea that the media are not neutral means of communication that convey reality as it is. As Stuart Hall showed, they are rather mighty tools 
through which significance is constructed, often even in opposition to material reality, e.g. by means of selection, omission and presentation of information, where and how certain topics are presented to a broader audience. All these factors have the power to influence the recipient's understanding about the message (Hall, 2009).

For this reason, the sources used are mainly articles related to football and economy from widely read and/or influential German media and thus representative ones, such as the tabloid Bild, the news magazine Der Spiegel, the daily newspapers Süddeutsche Zeitung (SZ), Die Frankfurter Allgemeine Zeitung (FAZ), Die Welt, and the weekly newspaper Die Zeit Books and films that enjoyed significant or broad reception and impact in Germany were also taken into consideration.

For the same reason, the diachronic line spanning this article considers mainly GFR history from the end of WWII up to now. The former German Democratic Republic (GDR) will hardly be taken into account since it played little if any constitutive role in the German national narrative up to now except as a ex negativo example in the light of which GFR achievements shine even more brightly.

\section{3. 'Elective affinities'}

As already touched upon and as will be specified in the following, the subsystems football and the economy share with nationalism some central principles that allow them to interact and thus explain the interdiscursive dynamics between them, mainly the relevance of inclusion and exclusion mechanisms, the rhetoric of competition and success, and German virtues.

Considered by itself, football, the most popular sport in Germany, operates with a strong mechanism of identification and exclusion (Markovits, 2011) which is also key in nationalist narratives. On one hand, there is an inner identification with one's own team, and on the other hand the competition against the other team, which in turn strengthens inner group cohesion. For the duration of the game, the fans forget themselves and merge emotionally with the community, the majority of whom they do not know. In fact, football became one of the few areas in highly individualised and rationalised mass societies that enables the expression of collective emotions and provides an important source of identification with a collective community, similar to a nation in the sense of 'imagined communities' (Anderson, 2006). The medial spectacularisation of sports reporting has strengthened this effect (Daalmann, 1998, p. 39) and can even play a major role in promoting a sense of collective national identity (Bishop \& Jaworski, 2003, p. 249).

In addition, the competitive physical dimension involved in football can satisfy a need for trials of strength that does not exist in a socially acceptable form elsewhere in most modern societies. Competition, losing or winning against a team, measures and serves self-definition and the delimitation towards the other - not only on an individual level but also regional and national. As we know, football provides a popular venue for competitions between nations that were common in the past but would not be possible on the political level today, an aspect that the media often exploits in games between nations by drawing on military imagery and metaphor in their reports (Bishop \& Jaworski, 2003, p. 250).

Whereas the productive 'dialogue' between football and nationalist discourses is hardly questioned nowadays, ${ }^{8}$ it is less obvious between these and the 'cold, technocratic' 
subsystem 'economy'. Nevertheless, the economy has played an enormous role in postwar self-esteem and in the rearticulation of German national identity. By highlighting German specificities such as the idea of the Volkswirtschaft, the relevance of familyowned companies and the alleged superiority of German values as the explanation for German economic success, a subtle nationalist perspective has been nurtured. Volkswirtschaft, literally designating the 'people's economy', suggests the existence of an almost autocratic German national economy. Furthermore, the notion of family-owned companies as well as so-called German virtues suggest a certain homely cosiness that makes it easy to forget that Germany exports its products all over the world on credit.

The so-called 'German virtues' - hard work, sense of order, precision, and team spirit have been re-evaluated in both economic and football discourses. Because they were perceived as the veritable basis of German success, they became again important elements of national identification and even pride. This was not self-evident, though, as they were basically the Prussian virtues, which had fallen into disrepute, principally among the generation of ' 68 and the student revolt for being authoritarian and not having prevented National Socialism. ${ }^{9}$

The following sections will thus illustrate from a diachronic perspective how these 'elective affinities' and the considerable success Germans achieved in football and the economy in the post-war time paved the way toward a growing identification with their own country and to the process of re-defining a nation that had to be built up again from scratch, even if that often requires reading 'between the lines'.

Drawing on the events the 'Miracle of Bern' and the 'Economic Miracle', part IV will show how football and the economy operated as a space of retreat and as an experimental field for the subtle re-verbalisation of post-war identity. Part $V$ will delineate the longing for 'normality' and nationalist self-assertive tendencies mainly after the reunification, whereas part VI will focus on the central role of the economy in the process of a positive identification with the nation. Often represented as a German battlefield or football pitch that has to assert itself in a highly competitive Darwinian world, the economy and the label 'made in Germany' was like a national football team and the denomination 'world champions of exports' was the trophy Germans regularly won thanks to their virtues.

Strikingly, the following sections will not only illustrate the importance of football and the economy with its principles of competition, success, and German values for the postwar national narrative, but also disclose a 'development', as it retrospectively contains a powerful teleological force that national myths require, ${ }^{10}$ even if it is not openly expressed. The post-war 'myth' that those economic and football episodes reveal - and that goes beyond the rational 'constitutional patriotism' of Habermas (Habermas, 2009) - is basically the history of the German Volk defeated in the war, whose country had been massively destroyed and occupied by the Allies, but thanks to German values quickly rose from the ashes, dealt with its guilt, was rewarded with reunification and managed to become the leading European country within the span of only a few decades.

\section{Football, the economy and national identity in the post-war period}

After World War II, Germany was in a shambles at all levels: 20 percent of all housing was in ruins and food production per capita in 1947 was only 51 percent of its level in 1938. Industrial output in 1947 amounted to only one-third of its 1938 level, and a large percentage of 
Germany's working-age males had perished in battle. The daily challenges made survival and reconstruction a top priority. Identity-oriented national issues were rendered secondary.

Yet, only ten years later, the Western German economy was thriving. In 1950, it achieved a growth rate of $10.9 \%$ and there was a great export surplus. Industry production grew by some $150 \%$ from 1950 to 1960 . Already in 1954, the GFR was the third-largest trading nation after the US and Great Britain (Herbert, 2014, p. 623). In 1965 real wages were already twice as high as in 1950 and from 1957 there was also a progressive growth in pensions.

The catchword 'economic miracle' was coined for this rapid growth and feeling under Chancellor Adenauer and his Minister of Economics Ludwig Erhard after years of deprivation. It marked the beginning of a strong West German emotional identification with it and its currency, the 'Deutsche Mark' (Von Beyme, 1999, p. 48) - even today a collective site of memory (James, $2002^{2}$ ) - as an element of stability and prosperity after the negative experiences of the Weimar period, World War II and its immediate aftermath. Even though the outstanding economic performance was a Western European phenomenon, the result of a favourable situation (Herbert, 2014, p. 620) and of the US-America Marshall Plan, it was felt as particularly spectacular in West Germany, so to say, as a national specificity that boosted West German national self-confidence (Von Beyme, 1996, p. 88), the confirmation of German strength, and to a certain extent even as compensation for the German defeat and territorial losses (Herbert, 2014, p. 621).

Not only did the quick economic recovery feed the collective feeling of being somebody again, but also the social market economy, which fused market and social responsibility. Thus, it took a domestic cohesive function and it united a politically lacerated nation and diverse population that had integrated millions of new inhabitants after the war, namely 10 million expellees from Eastern Europe and three million refugees from the Soviet Zone and later GDR. Furthermore, the economic success of the social market economy paved the way to the acceptance of and even identification with parliamentarian democracy and the integration into the Western bloc (Mommsen, 1983, p. 176).

The West German population enjoyed new prosperity and freedoms, including that of consumption. The Nazi past was repressed both through a form of national amnesia and legally-based amnesty. Thanks to instalment credit, almost everyone could afford new commodities, such as the new Bauknecht fridge or Grundig radio. The Volkswagen, the 'rolling economic miracle' (Schütz, 2002, p. 352) - today a 'lieu de mémoire - became the symbol of German 'craftmanship' and virtues, of the economic revival par excellence and the best German 'ambassador' abroad, where it was also eagerly bought (Schütz, 2002, p. 366).

In an article on the celebration around the production of the 1 millionth Volkswagen car in 1955, Der Spiegel made this productive relation between economy and national identity very visible, also on the discursive level. The industry and the 'economy' were depicted in a clear analogy to a competition field, in which some win and others are excluded from the sphere of success and profit. Volkswagen's success was seen as the result of the company's manager's competence and the product's quality. Drawing on martial imagery, the news magazine compared Henrich Nordhoff, the Volkswagen manager at that time, to a king and a 'captain' who had 'conquered' several foreign markets in fierce competition against English, American, French and Italian car exporter nations and thus led his 
'troops', that is, his workers and the city of Wolfsburg, into victory and prosperity. The article ended describing Nordhoff's church attendance to a king who thanks god after a conquered battle. ('Volkswagenwerk. In König Nordhoff's Reich' 1955, p. 26).

In a similar way, football contributed to the rehabilitation of the German nation after the war and the reinforcement of the 'Wir sind wieder wer' ['We're someone again'] feeling, as Helmut Kohl observed retrospectively referring to the German victory in 1954 in Berne (cf. Seitz, 2004, p. 4). Nine years after capitulation, the Allied occupation and all the deprivations, the GFR won the championship 3:2 against the favourite Hungarian team. The national relevance of this central, if not the most important single event in the process of German post-war identity formation (Daalmann, 1998, p. 47) - and now a site of memory (Groll, 2007, p. 183) - was already recognised at that time: Der Spiegel astutely observed that the enthusiasm for sports came to replace the former enthusiasm for politics, that is, sports then took on the task of canalising feelings that in the past had been reserved for national achievements, but became unacceptable in politics and would give it an undesirable note ('Herberger' 3:2, 1954, p. 21). It thus described the game as the continuation of the war between European powers ('Bundestrainer Adenauer', 1954, p. 16), and compared it to the 'Endsieg' (Leinemann, 1996, p. 120), and to the 'coronation of the British queen' ('Bundestrainer Adenauer', 1954, p. 16). The historian Joachim Fest classified it as a kind of 'liberation' (Seitz, 2004, p. 4), because of the atmosphere of optimism and renewal it triggered and because it helped to integrate the GFR within the community of nations. Also branded as a 'miracle' into collective memory, namely 'the Miracle of Bern', the film director Sönke Wortmann revived this myth with his film Das Wunder von Bern (2003) before the 2006 World Cup in Germany. Inspired by this success - approximately four million watched it, - a musical on the topic was also produced, ${ }^{11}$ depicting the national team's behaviour as exemplary for many Germans: hard work, discipline, efficiency, team fighting spirit and success - precisely those 'German virtues' that were also vital for the much-lauded 'economic miracle'.

\section{Between the wish for 'normality' and the national "coming-out"}

Whereas the West German population in the 1950s was largely consumption-driven and future-oriented, this social apolitical 'pragmatical consensus' was no longer valid for the following generation, born in a prosperous society and for whom the enormous hardships of the reconstruction period represented no more than a pale memory (Mommsen, 1983, p. 178). While their parents desired to repress the past, the National Socialist history caught up with their children in the 1960s. A series of events contributed to the gradual awareness, including inter alia the Nuremberg Trial (1944/45), the Eichmann Trial (1960), and the Auschwitz Trial (1963). The generation of ' 68 demanded a critical and collective confrontation with this past, a process that became known as Vergangenheitsbewältigung. Willy Brandt's kneeling before the Warsaw Memorial in 1970 or Weizsäcker's speech on 8 May 1985, in which he called it a 'day of liberation not of defeat', are examples of this new perspective on national history.

Against this background, national symbols and patriotism in general became taboo subjects. However, for a more conservative, patriotic segment of West German society, the critical approach to the past was felt as oppressive over the years (Mommsen, 1983, p. 181; Walser, 1993). Also, younger Germans had the feeling that they themselves had 
little to do with this chapter of history. ${ }^{12}$ They wearied of being regularly confronted at school and in the media with the horrors of the Holocaust. Instead they longed for a 'normal' or even positive identification with their country (Hagemann \& Nathanson, 2015, pp. 22-31), a wish that became stronger after the German reunification.

This historical event was perceived by many as a step towards 'normality' itself, as it put an end to the Cold War and the German divide, and marked the beginning of the consolidation epoch of the new German state. Although German nationalist attitudes continued to remain the lowest among all EU nations in the 1990s (Von Beyme, 1999, p. 47), in some segments of German society there was a growing distance towards the critical discourse and intellectuals such as the left-wing Günter Grass or the conservative Ulrich Greiner questioned whether Germany was a nation at all (Greiner, 1990) on the past, the 'negative nationalism', as August Winkler put it (Winkler, 2000, p. 446), or dissociation from the 'memory culture' that tried to keep the memory of the German crime alive. Martin Walser's speech in the Frankfurt Paulskirche in 1998 against the German memory culture and the 'moral cudgel' of Auschwitz is probably the most prominent example of this paradigmatic shift, despite the criticism it attracted.

In parallel with this, there were also attempts to portray Germans as victims, and not only perpetrators of war and history, e.g. Jörg Friedrich's book Der Brand. Deutschland im Bombenkrieg 1940-1945 (2002) about the bombing of German cities and Günther Grass's Im Krebsgang (2002) about the sinking of the ship Wilhelm Gustloff with around 10,000 German expellees on board. Various monographic studies attempted to achieve a positive identification with Germany, such as Was die Gesellschaft zusammenhält. Plädoyer für einen modernen Patriotismus, released by the Konrad Adenauer Foundation in 2004 (Buchstab \& Gauger, 2004), Hajo Schumacher's Kopf hoch, Deutschland (2005), Udo di Fabio's Die Kultur der Freiheit (2005), Matthias Matussek's Wir Deutschen. Warum uns die anderen gerne haben können (2006), or Florian Langenscheidt's Das Beste aus Deutschland. 250 Gründe unser Land zu lieben (2006).

All these events, releases and publications were more or less the subject of spirited public debate. But no event has had such impact on national identity as the 2006 World Cup in Germany (Grabbe, 2014, p. 15). This championship can even be classified as a watershed in terms of national identity. 'A summer tale changed Germany', is how the conservative $F A Z$ described it ('Ein Sommermärchen veränderte Deutschland', 2006). According to Der Spiegel, the World Cup had transformed the country: more relaxed, friendly, with football dominating hearts, heads and every corner of the country ('Deutschland, ein Sommermärchen', 2006). Although the German team lost in the semi-final against Italy and garnered only third place after a 3:1 victory against Portugal, there was a festive atmosphere all over Germany for four weeks (Gertz, 2006, p. 3). The trainer Klinsmann had managed to transform a country of whiners and pessimists into emotional, friendly and enthusiastic, people, Der Spiegel claimed. Whereas Germans in 1989 celebrated among themselves, now they did it with the world ('Deutschland, ein Sommermärchen', 2006).

In a certain way, the 2006 World Cup was a liberating moment. For the first time since the end of the war, many Germans felt free to show their national feelings, for example carrying national symbols like flags, or dress in national colours. The sociologist Dagmar Schediwy summoned this up as a 'national coming-out' of emotions that had been under an implicit taboo before. ${ }^{13}$ After interviewing many fans during the championship, Schediwy came to the conclusion that it was mainly the younger generation, in a sense the 
'millennials', who opposed the idea of German history being reduced to the Holocaust (Schediwy, 2012). Having felt the lack of a feeling of community in their everyday life, they wanted to express that they stood by their country (Schediwy, 2012). But more than anything else, Germany celebrated itself as a reunited country, or to put it in another way and echoing the football legend Frank Beckenbauer - a country such as the dear Lord would like it to be. ('Franz Beckenbauer zieht Bilanz', 2006).

Yet, the World Cup 2006 was more than a sports event and 'party'. In contrast to the 1954 championship, the enthusiasm was also the result of a top-down process of 'nation branding'. It was a well-organised publicity campaign for positive patriotism, and the calculated attempt to sell the brand 'made in Germany' using marketing techniques (Grabbe, 2014, pp. 84-87; Lianos, 2006).

Well aware of the power of football in Germany and that international competitions like the World Cup were a good chance to present a country and its economy to the world (Heyne, 2006), football organisers, the German government and industry seized upon this opportunity, endeavouring to disseminate the image of a modern and tolerant nation, as the championship's motto reflects: Die Welt zu Gast bei Freunden. The literal translation: 'The world as a guest at a friend's place' or 'Friends welcome the world' conveys the motto's intention better than the official translation 'Time to make friends' and passes on the message that a reunited Germany 2006 was an amicable country, one which welcomed the world with open arms.

The highly influential Bertelsmann Foundation, together with 25 media companies, launched a huge social marketing campaign Du bist Deutschland ['You are Germany'] in 2005. The text, in which enthusiasm for the country is metaphorically compared to enthusiasm for a football team or sports hero ['Du bist Deutschland' 2005], aimed at promoting positive thinking in Germany, including towards one's own country, since optimism was also regarded as vital to enhance Germany's image in the world and stimulate consumption and the economy in general.

At the same time, the German Chancellorship, the interior ministry, and German industry gathered 20 million euros from taxes and industry donations for the purpose of 'nation branding'. Together with the advertising agency Scholz \& Friends and under the patronage of the president Horst Köhler, they launched the campaign under the motto: 'Deutschland, Land der Ideen' [Germany, Country of Ideas] in order to promote the image of Germany as a land of knowledge and innovation (Grabbe, 2014, p. 89).

The well-orchestrated World Cup was only briefly disturbed by the ensuing unexpected discussion in the media on racism and on so-called neo-Nazi controlled 'no-go areas' (Heye, 2006). The German African Council had triggered this debate by announcing its intention to publish a map with the areas that Black visitors should avoid during their visit in Germany in order to prevent them from being victims of racist attacks.

Although this initiative tackled a different face of German nationalism, the problem of racism, and was a reminder that the population's growing diversity was not being appropriately reflected in public discourse, it was soon forgotten by politics and the media. The debate thus ended up as a minor disruptive intervention that did not undercut the impact of the whole event and had no influence on migrants' everyday lives. ${ }^{14}$

Statistics show that the plan was successful with the media embracing the party atmosphere and operated as a resonance space and multiplicator. The championship enhanced Germany's image (Kamps \& Nieland, 2007, p. 573), not only foregrounding familiar 
qualities such as efficiency and talent for organisation, but also completely new attributes, like coolness and cheerfulness - a kind of the German version of 'cool Britannia'. The journalist Christoph Marx summed up the championship's powerful impact:

The World Cup was the best advertisement for the new reunited Germany. Inebriated by the good weather, the hosts presented themselves as a modern, open society. And the German players of the Swabian Siegfried Klinsmann realized that they needed no victory to win. (Marx, 2014)

Once again, the film director Sönke Wortmann, who had been involved in Gerhard Schröder's national branding campaign (Grabbe, 2014, p. 84), tried to capture this atmosphere in the film Sommermärchen ['Summer Fairy Tale']. Wortmann's cooperation with politics is a good example of how the close interrelation between football, the economy and nationalism had indeed been strategically planned. As in his earlier work Das Wunder von Bern, this film offers strong images galvanising a positive emotional identification with Germany. Wortmann consciously took up the football's nation building narrative of the fifties and gave it continuity after the reunification. ${ }^{15}$ The title, an allusion to the Jewish poet Heinrich Heine's work, is revealing as it suggests that there is no need to worry about Germany like Heine did in his time, but reason to trust and celebrate along. ${ }^{16}$ If the Miracle of Bern celebrated the birth hour of the G.F.R. based in Bonn, one can say retrospectively that the Summer Fairy Tale marked its end and the beginning of the reunited Germany with Berlin as its old-new capital. Both films celebrated national unity, economic success, and depicted Germany as the 'fairy tale of the economic miracle' (Grabbe, 2014, p. 262). And it is certainly no coincidence that the film's premiere was planned for October 3rd, the national day of German unity, and set at the centre of the new Republic, on Potsdamer Platz in Berlin, and was viewed by leading politicians like Angela Merkel.

\section{World champions in football and exports}

The impact of the 2006 championship in terms of national identification was only exceeded - and in a sense reached a culmination - in the World Cup victory in Brazil in 2014. This time, Germany became not only 'winner of the hearts' like in 2006, but really did win against its competitor Brazil, the World Cup host, in the semi-final and against another highly respected South American country, Argentina, in the final. Secondly, the victory took place in Brazil, an important football country, which has had the highest number of participations in World Cup games and had won the greatest number of World Cup titles. Thirdly, concomitant was a very successful political-economic climate in Germany. Whereas most European countries were still struggling with the effects of the financial crisis and especially Southern European countries were experiencing record levels of unemployment, Germany was going through a 'second economic miracle'. In the light of this, the 2014 World Cup was more than a simple victory in sports. In a certain way, it was conveyed and perceived also as the triumph of the 'German model' in Europe and the victory of distinctively 'northern' virtues such as discipline, organisation, and collective willpower over more 'southern' attributes, as symbolised in this case by the Latino-American countries Brazil and Argentina. The journalist Jürgen Schmieder was not able to hide an undertone of reprove of the Argentinian president's lack of sense of duty and patriotism in his article in the SZ: 'Argentinien nach der 
Niederlage. An Alemania gescheitert - schon wieder. Hört das nie auf?' [Argentina after the defeat. Failed against Germany again. Will this never stop?] (Schmieder, 2014). Reporting on the third German victory over this Southern American country in a world championship, Schmieder remarked that Cristina Fernández de Kirchner's attendance would have reassured the crisis-ridden country. Despite this and being surprisingly healthy and fit enough for other important appointments, she decided to miss the final game apparently due to illness.

As Schmieder's observation betrays, football and the economy are basically represented as being intrinsically intertwined, as sharing the same values and same fighting spirit in a highly competitive world. The pride of being a successful football nation is similar to the pride of having a strong economy. Even the same language register was employed in describing the title of champion of exports and a football title, as the following extract from a FAZ article, and two texts on the economy from the internet page of the Munique Business School by Heiko Seif and in the news magazine Der Focus also illustrate:

German WM performance is a symbol of the success of the country in general: France sees it as a mirror of our economic power, Argentina acknowledges the German virtues. ('Deutsche Disziplin und Effizienz', 2014).

Especially for Germany, the year 2014 was a total success. We have world-champion-like qualities not only in football, but also in exports. And this is known all over the world. 'Made in Germany' stands for quality, efficiency, precision - on the international scale. [...] For these reasons Germany gets the title 'champion of exports' year after year. (Seif, 'Exportweltmeister Deutschland', 2014)

We are going to take the title from the US. German economy wants to become Vice Champion in exports. According to the estimates of the economy expert Volker Treier, Germany will advance this year to vice-championship of exports behind China. By doing so, it would dislodge the US from second place. ('Werden den USA Titel abluchsen ... ', 2013)

This 'libidinous' relation to the economy, about which Jürgen Habermas expressed his concerns in 1990 (Habermas, 1990), ${ }^{17}$ gained special momentum in the form of 'export nationalism' after the reunification. Inspired by mercantilist premises, nations were seen like firms or football teams that compete with each other. Germans products were depicted as the result of German virtues and internationally appreciated 'quality work' [Wertarbeit] - the key to German success in a highly competitive globalised environment. As a result, Germany kept winning the title 'world champion of exports', a term that popped up in the in the media repeatedly (cf. e.g. 'Exportweltmeister. Deutschland hängt China ab', 2017, 'Export-Weltmeister. Mit welchen Produkten Deutschland den Weltmarkt dominiert' 2017, Birger 2018).

Product quality doubtless played a central role in the German performance and competitiveness. But they were also the result of the massive 'reforms' under Chancellor Gerhard Schröder that entered history as 'Agenda 2010'. Those measures were basically a domestic agenda of austerity and consisted of massive labour cost reductions, and elimination of social security contributions on low-paid jobs. They led to a huge decline in unit labour costs in Germany at a time when they were rising elsewhere in the Eurozone, and thus to an increase in German competitiveness (Kundnani, 2014, p. 75). This effect, along with the new emerging markets outside Europe, caused a manufacturing boom that began to 
be clearly perceived particularly after Angela Merkel became chancellor in 2005. Germany went from a trade deficit of 1.7 percent of the GDP in 2000 to a surplus of 7.4 percent in 2007, in 2016 reaching a record 9\% surplus. As domestic demand remained low due to loan restraint, the economy became more dependent on exports than it had been before. In parallel, unemployment, the big problem in Germany for decades, began to fall.

Thus, German export success did not exist by itself as this 'export nationalism' suggested. As part of the EU, Germany shared the same market with other European countries and has been greatly profiting from the undervalued euro. Besides, it has been unbalancing the European economy due to the continuing export surplus, disrespecting European stability criteria and it would not be a sustainable strategy if all European countries were to choose the same path.

Despite this, politicians made no effort to explain the mechanisms of the European Union, the complexities of the so-called 'euro crisis', and the entangled economic relations in globalised times. They also kept silent about the fact that Germany industry was not only exporting its goods but that German banks were also giving credit to foreign countries to finance them and causing a debt spiral again. Besides, they were thus running the risk of exporting the wealth the country was producing without getting the respective payment in return (Fratzscher, 2014).

Instead, politicians and the media argued mainly from a national neo-classical perspective during the 'euro crisis' (Hermann, 2016) and presented the German success story as a model to follow. Angela Merkel herself demanded that Southern Europeans should not only spend less money, take fewer holidays and retire later, but also implied that they should follow the German example and work harder: 'We cannot have a single currency and one having many holidays and the other few. This does not work out in the long run.' (Gathmann \& Medick, 2011). With regards to the credits for Southern European countries, Merkel announced: 'Yes, Germany helps, but Germany helps only if all make an effort. And this needs to be proven' (Merkel attackiert urlaubsfreudige Südeuropäer, 2011). The chancellor's comments were perceived as an unexpected paradigmatic shift with regard to discourse on Europe. The Social Democratic Party leader, Sigmund Gabriel, criticised her for stirring up anti-European resentment and for overlooking other responsible actors and entities for the crisis: exchange rate speculators and investment bankers (Gathmann \& Medick, 2011). Although Angela Merkel maintained her general technocratic style despite those initial forays against Southern Europe, politicians from her party, mainly from the more conservative fraction, abandoned their long-maintained post-war reserve in a way that was perceived as selfcentred, and non-European. The economy was used for punishing and justifying a new openly nationalistic discourse both in politics and the media. One example of this is the phrasing 'Europe speaks German now' that Volker Kauder, the parliamentary leader of the CDU, articulated in 2011 to critique the European budgetary policy and to present Germany as the model, to the dismay of many European members. This derogatory nationalistic discourse became dominant particularly during the Greek bailout in 2015. Kauder, who in 2012 urged the Greeks to do their homework (Bröcker \& Mayntz, 2012), even called the Greek prime-minister a 'cheeky chap' ['freches Bürschchen'] (Meier \& Kneist, 2015). Finance minister Wolfgang Schäuble's son-in-law, Thomas Strobl, now minister of the interior of the state of Baden-Württemberg, even commented at the time that 'The Greeks have long got on his nerves' (Schuler, 2015). But it was especially Schäuble's brash attitude that was perceived in Europe as arrogant and nationalistic. 
The German media contributed to this impression by drawing on culturalistic patterns to depict the European crisis, such as the 'hard-working German' versus the 'lazy southerner'. The most popular tabloid Das Bild with ca. 10 million readers is an example of this. Instead of depicting the difficult international economic and political ramifications, it explained the problem with simplistic images and structures, mainly with the dualism 'we-they', 'friend-enemy'. The roles were clearly divided: The Germans stood for the positive, the diligent, the latter, the Südländer, for the negative, the lazy and wasteful. For instance, on 27 April 2010, the Springer tabloid put out an article with the polemic title: 'Dispute over Billions Aid: Why do we pay the Greeks' luxurious pensions? Greek pensioners are so fortunate' (Hoeren \& Santen, 2010). Bild even advised: 'Sell your islands, you bankrupt Greeks, and the Acropolis, too' (Verkauf doch Eure Inseln, 2010).

Although less stridently, the news magazine Der Spiegel basically followed the same line. On its magazine cover of 31 January 2015, the new Greek prime minister was even labelled as 'Europe's nightmare' and the 'wrong-way driver' (Bloeme, Ertel, Heyer, \& Knaup, 2015). Tsipras was depicted as 'sexy Alexi', as the smart, good-looking politician, to whom female voters feel attracted (Ervedosa, 2017).

Almost 30 years after reunification and 16 years after the introduction of the euro, the finance crisis underscored that economic leadership can easily turn into nationalist dominance. Seventy years after the war, Germany was the political European hegemon due to its economic weight. However, it offered no visible political European vision; nor did it hold out a sustainable language to communicate with its members. Although the German negotiation style was perceived as an affront to many Europeans, international reactions to it and its consequences hardly penetrated German public opinion. Instead, the domestic popularity of Merkel and Schäuble rose after the Greek bailout thanks to the way they had conducted the negotiations (Griechenland-Verhandlungen, 2015).

One of the most important meetings in the field of economy, The GR-7 summit in Elmau, Bavaria, in June 2015 during the Greek crisis can be seen as a climax of German economic power and national self-satisfaction. Significantly, the most circulated photo of this event in the German media was Michael Kappeler's picture showing Merkel standing before an idyllic Alpine panorama stretching her arms out in a self-confident manner, as if explaining the world to the most powerful president in the world, Barack Obama, who is shown listening attentively, sitting on a bench, his back to the photographer. This photo spread quickly in the German media (Das letzte Geheimnis des Merkels-Obama-Fotos, 2015), supposedly not only because of its enigmatic character, but also because it evokes the image that was appreciated: a country that has succeeded in becoming European and an export leader thanks to the quality of the label 'made in Germany'. Hosting such a central economic and political international summit and receiving the most powerful heads of state are tantamount to an expression of such success and the kind of inward self-centred nationalism that Germany was celebrating - the world comes to Germany due its economic success and power. Germany does not have to leave its 'idyll', only its export products do.

\section{Conclusion, or the fragilities of football and the economy as surrogate discourses}

In his article 'Die Ästhetik des Staates revisited' [The Aesthetics of the State revisited] in 2006, the literature theorist Karl Heinz Bohrer complains about the extreme functionalism 
that has characterised post-war Germany. He critiques the state's lack of aesthetics and style, as well as the importance of the parochial German idyll (Bohrer, 2006, p. 749). In fact, precisely this functionalism, the lack of an official national discourse and the (non)aesthetics of the label 'made in Germany' are central characteristics of post-war Germany. They do not convey the refined, cosmopolitan style that Bohrer misses, but a sober technocratic one.

Yet this does not mean that nationalism in the Bonn republic had been eradicated. It rather means that politics avoided nationalistic overtones and emotions and handled them very carefully. When it was deemed advantageous to resort to it, this was done rather latently and 'between the lines'. Due to their popularity and apparent 'neutrality', economic and sports enabled a gradual and careful approach to collectiveness and to expressions about German achievements, virtues and even pride.

The concentration on the economy and the reduction of politics to a managerial function worked quite well in the GFR, since it constituted a form of relief and disengagement from the extremely ideological pre-war decades. In addition, it was a way to reassert Germany's 'neutral' interests in a post-war Europe which looked suspiciously at Germany. Because of the prosperity and the welfare system the German post-war economy brought about, it proved to be internally extremely cohesive: it united a heterogeneous traumatised population busy coping with the challenges of everyday life. Consequently, the German currency, the Deutsche Mark, became a 'neutral' factor of identification for many Germans at the time, given that it symbolised the successful post-war reconstruction, stability and prosperity for the majority of the population. The post-war economic achievements also proved to be integrative in external matters, as Germans accepted the new political and economic system of the Western bloc, although the Eastern territory of Germany as the GDR did not integrate into it. We have seen that football also fulfilled a similar integrative function, both domestically and externally.

Yet the reunification and the introduction of the euro changed Germany's position in Europe. The German economy emerged more robust from the creation of the Eurozone, which strengthened Germany's status on the continent. In fact, Germany became the main economic and consequently political force in Europe, if not indeed the veritable 'hegemon'. ${ }^{18}$

Despite this new European constellation, Germany focused on national interests, also when forced to find solutions for all Europe, as during the euro crisis or in the question of the massive export surplus. The economy was thus no longer perceived as a unifying but rather as a dividing factor. The technocratic language that had been effective in the past left a vacuum that revealed the lack of ideas for the European project.

On the domestic front, the technocratic language also left a political void that the 'world-champions' and the 'German virtues' rhetoric both in the economy and football could no longer fill. Even though the negative effects of German export nationalism were hardly publicly discussed in politics and media, many Germans felt that they were not benefiting from this second 'economic miracle' in their daily lives. Wages had decreased, health care benefits had been cut, the state became leaner, and there was not much public and private investment. In general, the challenges that German society had been facing since reunification, including the growing diversity and inequality ${ }^{19}$, showed that the economy, a former factor of cohesion, threatened to become a cause of division also on the domestic level. 
One year after the 2014 World Cup, only a few months after the Greek bailout and the Elmau summit, the refugees that entered Germany - and precisely the 'idyllic' German South - were enough to shatter national self-confidence violently. This new situation, and series of terror attacks, in particular in 2016, quickly transformed the atmosphere in Germany. Within the short span of only several months, the political and social texture changed drastically from a 'welcoming culture' to almost daily, arson attacks against refugee centres occurred. As so often regarding questions of national identity and nationalism in Germany, the new national self-confidence thus proved to be fragile.On top of this, numerous scandals came to light involving important institutions and companies such as Deutsche Bank, Commerzbank, Siemens, Volkswagen, Opel and Bosch which in the past enjoyed esteem as symbols of the German economy and its virtues, but now rather contributed to the climate of suspicion and insecurity.

As if this was not enough, the media reported in 2016 that even the 'Summer Fairy Tale' had been bought for millions and the football celebrity Franz Beckenbauer had been the chief negotiator. These scandals served to tarnish the self-image of national success that had only been achieved by means of German virtues only, whereas corruption and skulduggery are problems that beset other countries. The disenchantment culminated with the reaction of the German Football Association and of the national team to the heated debate over Mesut Özil's photograph with Recep Tayyp Erdoğan and Özil's refusal to play again for the team after being blamed for the failure in the tournament in Russia at group stage in 2018. Their silence and the missing expressions of solidarity reduced the so appraised German virtue 'team spirit', which the national team was supposed to stand for and which the epitome given to the team Die Mannschaft [the squad] in 2018 stressed, to an empty marketing slogan.

Although it took a while until domestic fears found expression in political discourse which until recently has tended to reproduce the view that the German population had never been better off (Tretbar, 2011) - this also left a growing political vacuum that football and the title of 'champion of exports' could no longer compensate. In the light of the growing inequality in Germany and Europe, that narrative of the Grand Coalition not only failed to present answers to situations in which solidarity was expected both in the domestic and European arena, but also missed an integrative force of the weaker nations and poorer members of societies, whose biographies do not fit that rhetoric of competition and success.

This political emptiness has since then been partially filled by AfD's nationalistic and anti-Islam rhetoric, which attracts people not benefiting from the economic system or afraid of the rapid changes due to globalisation, as well as those who share these views but did not dare to express such ideas in the past. This means that the AfD is responding more and more to this economic and social division with ideas of ethnic cohesion. Profiting from the lack of criticism towards the past in the former GDR territory and generous, opaque campaign donors ${ }^{20}$, this party has been hijacking national discourse based on ('biological') ethnic descent that promises the warmth of a familiar exclusive collective and protection from today's challenges. Despite the power, intensity, the anxiety and even hatred that this exclusive ethnic nationalism generates, it is weak in expression. It does not present a constructive idea of what the German nation and identity are in the 21st century, but only delineates it ex negativo in contrast with what is projected as the supposed 'other'. Thus, almost three decades after reunification, Wehler's dystopia is not 
absurd. The denigration or even negation of the 'other' could threaten to become the quintessence of a new German nationalism if politics does not soon find a mode of political discourse that gives voice to the new German demographic realities, ${ }^{21}$ and can adequately express genuine German anxieties and give voice to the country's role in Europe.

\section{Notes}

1. In his project on 'group-focused enmity' towards 'weaker groups', Heitmeyer argues that the German middle-class has become more prone to group-focused enmity, that education and higher income are no longer barriers against intolerance, and that stressing national pride makes intolerance towards those groups more likely (Heitmeyer, 2006, 2010).

2. In the regional state elections in 2016, the AfD achieved 15.1\% in Baden-Wuerttemberg, $24.2 \%$ in Saxony-Anhalt, and $12.6 \%$ in Rhineland-Palatinate. In the federal elections in 2017, it scored $13.3 \%: 11 \%$ in west and $21.5 \%$ in east Germany. A further symptom of altero-referential nationalism is the attention that Thilo Sarrazin's bestseller Deutschland schafft sich ab [Germany abolishes itself] (2010), and the extreme-right, anti-Islamic and anti-immigration Pegida movement received in the media and public sphere. The European Commission against Racism and Intolerance (ECRI) considered Sarrazin's book as an example of 'hate speech' and criticised the media for having given it great attention (ECRI, 2014, p. 20).

3. Guillaumin differentiates between self-centred and altero-referential societies. 'The first sort states 'we are different', whereas the second suggests 'they are different' (Guillaumin, 1995, p. 50). We defend that, due to its regional differences and troubled history, the 'other' has played an enormous role as counter-foil for self-definition.

4. People who have at least one parent who was born abroad and migrated to Germany after 1949. Many Germans do not consider the $19 \%$ of the residents with 'migrant background' (approximately half of them have a German passport) as 'real Germans' (Sachverständiger Rat, 2012).

5. Kundnani argues that Auschwitz separated German revolutionaries in the 60s from their European counterparts and that due to it the student mobilisation had a more lasting effect in Germany than anywhere else (Kundnani, 2009). In the article 'Heiliger Holocaust', the Jewish writer Maxim Biller wonders how Germans see the Holocaust as a pillar of national identity only several decades afterwards (Biller, 1996).

6. Form of patriotism oriented toward toleration, pluralism, and peaceful coexistence with other nations, rather than the aggressive hostility toward difference of earlier forms in German history (Sternberger, 1990; Habermas, 2009, pp. 106-118).

7. Since $9 / 11$ there has been a growing animosity towards Islam in Germany, too. The former president Christian Wulff's statement in 2010 that Islam is also a part of Germany was not well received by all Germans. Wulff's successor, Joachim Gauck, partially revised Wulff's statement in 2012. Although Angela Merkel reiterated Wulff's statement in 2015, the right-wing protest movement Pegida and the AfD made anti-Islamic sentiments one of the main points of their programme. For this reason, the current minister of the Interior, Construction and 'Heimat', the Bavarian politician Horst Seehofer, denied that Islam belonged to Germany as soon as he took up this position in March 2018. Merkel had to take corrective action by repeating that Islam is meanwhile part of Germany.

8. There are a significant number of studies on the relation between football and politics, among them: Daalmann, 1998; Seitz, 1990; Holz-Bacha, 2006; Schwier, 2006; Mittag \& Nieland, 2007.

9. According to the politician Oskar Lafontaine, German virtues are only secondary virtues that could also be useful to run a concentration camp (Serke, 1982, p. 55f). Rudolf Oswald sees the origin of some of these sentiments of collectivity in the folkish ideal of the 'folk community' (Oswald, 2007).

10. This apparent 'line of development' is not teleological in real terms but rather perceived.

11. Inaugurated in the Stage Theatre in November 2014. 
12. Only $47 \%$ of German pupils between 14 and 16 years know what 'Auschwitz-Birkenau' means (Forsa, 2017, p. 15).

13. Schediwy rejects the idea that the new national feelings and the use of national symbols were just 'fun-loving patriotism' and sees it also as a national 'coming out'.

14. According to Schediwy, many fans did not see the players' migrant background mainly as a sign of a pluralistic Germany. Rather, they saw it from a utilitarian perspective, that is, as a useful contribution to the German victory. They also served to 'sell' the image of a tolerant country. In fact, it did not have any visible positive influence on the 'migrants' in their everyday life. Only a couple of years later, Sarrazin's book Deutschland schafft sich ab (2010) would become a bestseller in Germany. According to Heitmeyer, nationalism increased after 2006 (Schediwy, 2012; Heitmeyer, 2012).

15. Carola Daffner shares this opinion (Daffner, 2011).

16. The title Sommermärchen is an allusion to Heine's book Deutschland, ein Wintermärchen (1844), in which the poet complained satirically about the political situation at the time. By alluding to Heine's work, Wortmann suggests that Germany deserves a positive identification.

17. Habermas complained that economic interests and a libidinous 'DM nationalism' threatened to dominate and swallow the political, republican consciousness of the newest German revolution.

18. The sobriquet that the British magazine The Economist gave to Germany in June 2013.

19. According to EU-SILC statistics, since $2008 \mathrm{ca}$. $20 \%$ of the population live under the poverty line in Germany (cf. Statistisches Bundesamt, 2016).

20. According to LobbyControl, the AfD received large intransparent donations through the organisation called the Verein zur Erhaltung der Rechtsstaatlichkeit und der bürgerlichen Freiheiten [Association for the preservation of the rule of law and civil freedoms] for its campaigns. It suspects these are illegal donations transferred over the Swiss firm Goal AG, which also supported the campaign of the Swiss right--wing party SVP and is linked to a rightwing European network, in order to circumvent German law which demands that donators must be published and prohibits foreign donations (Lobby Control, 2017).

21. The 'reunification' offered a unique opportunity for the promotion of a new, inclusive national narrative that reflects German demographic changes. However, it redefined the nation again along hereditary lines and a latent 'colour line'. The most visible expression of it was the violence in Solingen, Mölln, Rostock-Lichtenhagen and the positive welcome that Eastern Germans and 'ethnic' Germans from the former Soviet Union, Poland, Romania, etc. received, even if they hardly spoke any German, whereas darker-skinned citizens who had participated in West German life since at least the 1960s, were left out of the unification process (cf. Ayim's poem 'blues in schwarz weiss' (1990) in: Ayim, 2005 ${ }^{4}$ [1995], 82f. The topic 'foreigners' continues to be one of the most controversial ones in Germany, erupting anew every four or five years, as if for the first time (Herbert, 1995, p. 213, 2003, p. 9).

\section{Disclosure statement}

No potential conflict of interest was reported by the author.

\section{Funding}

This work was supported by Fundação para a Ciência e a Tecnologia [SFRH/ BPD/1011155/2014, UID/ SOC/50012/2013].

\section{Notes on contributor}

Clara Ervedosa holds PhD from the University of Kiel, Germany. She was lecturer and senior lecturer at the University of Trás-os-Montes e Altou Douro, Portugal. She taught and researched the universities of Sheffield and Manchester, UK, and at the University of Kiel, Germany. Currently she is 
senior researcher at the CES, University of Coimbra, and review editor (responsible for Postcolonial Studies) for the journal IASLonline (University of Munich). Her research interests include questions of identity and difference in postcolonialism in German Literature and Culture. She has published various articles on these topics.

\section{References}

Advertising Agency FischerAppelt (Producer). (2005). Du bist Deutschland. TV-Spot.

Anderson, B. (2006). Immagined communities. London: Verso.

Ayim, M. (1990). Blues in schwarz weiss. Idem ( $\left.{ }^{4} 2005\right)$, Blues in Schwarz Weiss. Berlin: Orlanda.

Biller, M. (1996, November 8). Heiliger Holocaust'. Die Zeit. Retrieved from http://www.zeit.de/1996/ 46/bill46.19961108.xml.

Birger, N. (2018, April 16). China besitzt jetzt die größte Containerflotte der Welt. Die Welt. Retrieved from https://www.welt.de/wirtschaft/article175474454/China-haengt-in-der-Container-SchifffahrtExportweltmeister-Deutschland-ab.html

Bishop, H., \& Jaworski, A. (2003). 'We beat'em'. Nationalism and hegemony of homogeneity in the British press reportage of Germany versus England during Euro 2000. Discourse \& Society, 14(3), 243-271.

Bloeme, N., Ertel, M., Heyer, J., \& Knaup, H. (2015, January 31). Der Wutgrieche'. Der Spiegel.

Bohrer, K.-H. (2006). Die Ästhetik des staates revisited. Merkur. Ein neues Deutschland, 9(10), 749-757.

Bröcker, M., \& Mayntz, G. (2012, June 23). Griechen müssen ihre Hausaufgaben machen. Rheinische Post. Retrieved from http://www.rp-online.de/politik/eu/griechen-muessen-ihre-hausaufgabenmachen-aid-1.2882358

Buchstab, G., \& Gauger, J.-D. (2004). Was die Gesellschaft zusammenhält. Plädoyer für einen modernen Patriotismus. Sankt Augustin: Konrad Adenauer Foundation.

Bundestrainer Adenauer. (1954). Der Spiegel, 29/1954, pp. $16 \mathrm{f}$.

Daalmann, A. (1998). Nationalismus in der Sportberichterstattung (Doctoral Dissertation). Universität Göttingen.

Daffner, C. (2011). Football, Mythology and Identity in Sönke Wortmanns Deutschland. Ein Sommermärchen. Austausch, 1(1). Retrieved from https://www.psa.ac.uk/sites/default/files/ Austausch\%2C\%20Vol.\%201\%2C\%20no.\%201\%2C\%20April\%202011\%20-\%20Daffner.pdf

Das letzte Geheimnis des Merkel-Obama-Fotos. (2015, June 10). Stern. Retrieved from http://www. stern.de/panorama/wie-das-foto-von-angela-merkel-und-barack-obama-auf-dem-g7-gipfel-in-elmauentstand-6290576.html

Deutsche Disziplin und Effizienz. (2014, July 14). FAZ. Retrieved from http://www.faz.net/aktuell/ wirtschaft/reaktionen-auf-den-wm-titel-deutsche-disziplin-und-effizienz-13045012/argentinierbewundern-deutsche-13045034.html

Deutschland, ein Sommermärchen. (2006). Der Spiegel, 25/2006, 69-81.

di Fabio's, U. (2005). Die Kultur der Freiheit. Munich: Beck.

Diner, D., Claussen, D., \& Brumlik, M. (1988). Zivilisationsbruch: Denken nach Auschwitz. Frankfurt: Fischer.

ECRI. (2014). Report on Germany. Retrieved from https://www.coe.int/t/dghl/monitoring/ecri/ Country-by-country/Germany/DEU-CbC-V-2014-002-ENG.pdf

Ein Sommermärchen veränderte Deutschland. (2006, July 7). FAZ.

Ervedosa, C. (2017). The calibanisation of the south in the German public 'Euro crisis' discourse. Postcolonial Studies, 20(2), 137-172.

Export-Weltmeister. Mit welchen Produkten Deutschland den Weltmarkt dominiert. (2017, March 23). Focus. Retrieved from https://www.focus.de/finanzen/videos/ausfuhren-export-weltmeister-mitdiesen-produkten-dominiert-deutschland-den-weltmarkt_id_6819514.html

Exportweltmeister. Deutschland hängt china ab. (2017, January 30). Bild. Retrieved from https://www. bild.de/geld/wirtschaft/export/eilmeldung-exportweltmeister-50026446.bild.html

Forsa. (2017, September 5). Umfrage Geschichtsunterricht. Berlin. Retrieved from https://www. koerber-stiftung.de/fileadmin/user_upload/koerber-stiftung/redaktion/handlungsfeld_international e-verstaendigung/pdf/2017/Ergebnisse_forsa-Umfrage_Geschichtsunterricht_Koerber-Stiftung.pdf 
Franz Beckenbauer zieht Bilanz. (2006). www.dfbnews.de. Retrieved from https://www.dfb.de/news/ detail/franz-beckenbauer-zieht-bilanz-es-hat-alles-gepasst-8136/?no_cache $=1$

Fratzscher, M. (2014). Die Deutschland-Illusion. Munich: Hanser.

Friedrich, J. (2002). Der Brand. Deutschland im Bombenkrieg 1940-1945. München: Propyläen.

Gathmann, F., \& Medick, V. (2011). SPD und Grüne werfen Merkel Stimmungsmache vor. Spiegelonline', 18 Mai. Retrieved from spd http://www.spiegel.de/politik/deutschland/kritik-ansuedeuropaeern-spd-und-gruene-werfen-merkel-stimmungsmache-vor-a-763334.html

Gellner, E. (1991). Nationalismus und Moderne. Berlin: Rotbuch.

Gertz, H. (2006, July 10). Abschied vom ganz normlen Helden. SZ.

Grabbe, K. (2014). Deutschland. Image und Imaginäres. Berlin: de gruyter.

Grass, G. (2002). Im Krebsgang. Göttingen: Steidl.

Greiner, U. (1990, March 16). Das Phantom der Nation. Die Zeit.

Griechenland-Verhandlungen. Merkel und Schäuble punkten bei den Wählern. (2015, September 8). FAZ. Retrieved from http://www.faz.net/aktuell/politik/inland/griechenland-verhandlungenmerkel-und-schaeuble-punkten-bei-den-waehlern-13710006.html

Groll, M. (2007). Wir sind Fußball: Über den Zusammenhang zwischen Fußball, nationaler Identität und Politik. In J. Mittag, \& J.-U. Nieland (Eds.), Das Spiel mit dem Fußball (pp. 177-190). Essen: Klartext.

Guillaumin, C. (1995). Racism, Sexism, Power and Ideology. London: Routledge.

Habermas, J. (1990, March 30). Der DM-Nationalismus. Die Zeit. Retrieved from http://www.zeit.de/ 1990/14/der-dm-nationalismus

Habermas, J. (2009). Vorpolitische Grundlagen des demokratischen Verfassungsstaates? In J. Habermas (Ed.), Zwischen Naturalismus und Religion (pp. 106-118). Frankfurt/M: Suhrkamp.

Hagemann, S., \& Nathanson, R. (2015). Deutschland und Israel heute. Gütersloh: Bertelsmann. Retrieved from https://www.bertelsmann-stiftung.de/fileadmin/files/BSt/Publikationen/ GrauePublikationen/Studie_LW_Deutschland_und_Israel_heute_2015.pdf

Hall, S. (2009). The Work of Representation. In S. Hall (Ed.), Representation (pp. 13-74). London: Sage.

Heitmeyer, W. (2006). Deutsche Zustände. Vol. 5. Frankfurt/M: Suhrkamp.

Heitmeyer, W. (2010). Deutsche Zustände. Vol. 8. Frankfurt/M: Suhrkamp.

Heitmeyer, W. (2012). Das Stadium ist der einzige Ort, wo Abwertugsmuster eine breite Öffentlichkeit erreichen - ohne Sanktionen. Online Akademie. Friedrich-Ebert-Stiftung. Retrieved from http:// library.fes.de/pdf-files/akademie/online/09871.pdf

Held, D. (1990). The Decline of the Nation State. In S. Hall, \& M. Jacques (Eds.), New Times: The Changing Face of Politics in the 90s (pp. 191-204). London: Lawrence \& Wishart.

Herberger. 3:2. (1954). Der Spiegel, 28, 21-25.

Herbert, U. (1995). Arbeit, Volkstum, Weltanschauung. Frankfurt/M: Fischer.

Herbert, U. (2003). Geschichte der Ausländerpolitik in Deutschland. Munich: Beck.

Herbert, U. (2014). Geschichte Deutschlands im 20. Jahrhundert. Munich: Beck.

Hermann, U. (2016). Kein Kapitalismus ist auch keine Lösung. Frankfurt/M: Westend.

Heye, U.-K. (2006, Mai 17). Rechtsextremismus. "No-go areas" in Ostdeutschland. Tagesspiegel. Retrieved from http://www.tagesspiegel.de/berlin/rechtsextremismus-heye-no-go-areas-inostdeutschland/712324.html

Heyne, M. (2006). Die ökonomischen Effekte von Fußballweltmeisterschaften. Marburg: Tectum.

Hobsbawm, E. (1990). Nations and Nationalism since 1780. New York: Cambridge University Press.

Hoeren, D., \& Santen, O. (2010, April 27). 'Warum zahlen wir den Griechen ihre Luxus-Renten?' Bild. Retrieved from http://www.bild.de/politik/wirtschaft/wir-zahlen-luxus-rente-mit-milliarden-hilfe12338430.bild.html

Holz-Bacha, C. (2006). Fußball- Fernsehen - Politik. Wiesbaden: Springer.

James, H. ( $\left.{ }^{2} 2002\right)$. Die D-Mark. In E. François, \& H. Schulze (Eds.), Deutsche Erinnerungsorte II (pp. 434449). Munich: Beck.

Kamps, K., \& Nieland, J.-U. (2007). Weltschaufenster Fußball. Kampagnen aus Anlass der WM 2006. In K. Kamps, \& J.-U. Nieland (Eds.), Das Spiel mit dem Fußball (pp. 573-586). Essen: Klartext.

Kundnani, H. (2009). Utopia or Auschwitz. Columbia: Columbia University Press.

Kundnani, H. (2014). The Paradox of German Power. London: Hurst. 
Langenscheidt, F. (2006). Das Beste aus Deutschland. Wiesbaden: Gabler Verlag.

Leinemann, J. (1996). Wie ein kleiner König. Der Spiegel 52/1996, 120-133.

Lianos, M. (2006). Fußball-Fieber Im Land der Ideen. In M. Köhler, \& C. Schuster (Eds.), Handbuch Regierung PR (pp. 275-286). Wiesbaden: Springer.

Link, J. (2011). Diskursanalyse unter besonderer Berücksichtigung von Interdiskurs und Kollektivsymbolik. In R. Keller, A. Hirseland, W. Schneider, \& W. Vierhöfer (Eds.), Handbuch sozialwissenschaftlicher Diskursanalyse, Theorien und Methoden, Vol 1 (pp. 433-458). Wiesbaden: VS Verlag.

Lobby Control. (2017). Hintergrundpapier September 2017, Cologne. Retrieved from https://www. lobbycontrol.de/wp-content/uploads/Hintergrundpapier_Verdeckte_Wahlhilfe_AfD.pdf

Markovits, A. S. (2011). Sport: Motor und Impulssystem für Emanzipation und Diskriminierung. Picus: Wien.

Marx, C. (2014). WM Geschichte 2006: Deutschland - die Welt zu Gast bei Freunden. Retrieved from http://www.marx-bloggt.de/tag/sommermaerchen/

Matussek, M. (2006). Wir Deutschen. Warum uns die anderen gerne haben können. Frankfurt/ M: Fischer.

Meier, A., \& Kneist, S. (2015, June 13). Volker Kauder nennt Alexis Tspiras freches Bürschchen. Der Tagesspiegel. Retrieved from https://www.tagesspiegel.de/politik/griechenland-volker-kaudernennt-premier-alexis-tspiras-freches-buerschchen/11911334.html

Merkel attackiert urlaubsfreudige Südeuropäer. (2011, May 18). Spiegelonline. Retrieved from http:// www.spiegel.de/politik/deutschland/euro-krise-merkel-attackiert-urlaubsfreudige-suedeuropaeera-763247.html

Mittag, J., \& Nieland, J.-U. (Eds.). (2007). Das Spiel mit dem Fußball. Essen: Klartext.

Mommsen, W. (1983). Wandlung der nationalen Identität der Deutschen. In W. Weidenfeld (Ed.), Die Identität der Deutschen (pp. 170-192). Bonn: Bpb.

Oswald, R. (2007). Vom Ursprung der deutschen Fußball-Tugenden im Volksgemeinschaftsideal. Die Berichterstattung der Fachpresse 1919-1954. In J. Mittag, \& J.-U. Nieland (Eds.), 2007), Das Spiel mit dem Fußball (pp. 83-94). Essen: Klartext.

Sachverständiger Rat für Integration und Migration. (2012). Benachtteiligungserfahrungen von Personen mit und ohne Migrationshintergrund im Ost-West-Vergleich. Berlin. Retrieved from http://www.antidiskriminierungsstelle.de/SharedDocs/Downloads/DE/publikationen/Expertisen/ Expertise_Benachteilig_Migrant_innen_Ost_West_Vergleich.pdf?_blob=publicationFile

Sarrazin, T. (2010). Deutschland schafft sich ab. München: dva.

Schediwy, D. (2012, May 22). Die Psychologie des Fußballpatriotismus. Publikative.org. Retrieved from http://publikative.org/2012/05/22/flucht-auf-die-fanmeile-die-sozialpsychologie-des-

fusballpatriotismus/

Schmieder, J. (2014, July 14). Argentinien nach der Niederlage. An Alemania gescheitert - schon wieder. Hört das nie auf? SZ.

Schnibben, C. (1993). Das deutsche Wesen. Der Spiegel 50/1993, 118-128.

Schuler, K. (2015, July 14). Der Grieche hat genug genervt. Die Zeit. Retrieved from http://www.zeit. de/politik/deutschland/2015-07/griechenland-strobl-union

Schumacher, H. (2005). Kopf hoch, Deutschland. München: Blessing.

Schütz, E. ( $\left.{ }^{4} 2002\right)$. Der Volkswagen. In E. François, \& H. Schulze (Eds.), Erinnerungsorte I (pp. 352-369). Munich: Beck.

Schwier, J. (2006). Die Welt zu Gast bei Freunden. In J. Schwier, \& C. Leggewie (Eds.), Wettbewerbspiele (pp. 79-104). Frankfurt: Campus.

Seif, H. (2014, December 19). Exportweltmeister Deutschland. Warum die Deutschen so elfolgreich exportieren. Retrieved from https://www.munich-business-school.de/insights/2014/ exportweltmeister-deutschland-warum-die-deutschen-so-erfolgreich-exportieren/

Seitz, N. (1990). Maradona \& Kohl. Frankfurt /M: Eichborn.

Seitz, N. (2004). Was symbolisiert das 'Wunder von Bern? Politik und Zeitgeschichte, 3-6.

Sennett, R. (1998). The Corrosion of Character. New York, NY: Norton \& Company.

Serke, J. (1982). Mein Sozi für die Zukunft. Der Stern, 15 July, 55-60. 
Statistisches Bundesamt. (2016). Pressemitteilung Nr. 391: Anteil der von Armut oder sozialer Ausgrenzung bedrohten Bevölkerung in Deutschland nahezu unverändert. Retrieved from https:// www.destatis.de/DE/PresseService/Presse/Pressemitteilungen/2016/11/PD16_391_634.html; jsessionid=3BE3BE289B3963446500B2B01CF7C9B1.cae2

Sternberger, D. (1990). Verfassungspatriotismus. In B. Vogel, P. Haungs, K. Landfried, E. Orth, D. Stenberger, \& R. V. Weizsäcker (Eds.), Schriften X (pp. 17-31). Frankfurt/M: Insel.

Tretbar, C. (2011, September 7). Merkel: Deutschland geht es so gut wie nie zuvor. Der Tagesspiegel. Retrieved from http://www.tagesspiegel.de/politik/generaldebatte-im-bundestag-merkeldeutschland-geht-es-so-gut-wie-nie-zuvor/4584808.html

Verkauft doch Eure Inseln, Ihr Pleite-Griechen, und die Akropolis gleich mit. (2010, October 27). Bild. Retrieved from http://www.bild.de/politik/wirtschaft/griechenland-krise/regierung-athen-sparenverkauft-inseln-pleite-akropolis-11692338.bild.html

Volkswagenwerk. In König Nordhoff's Reich. (1955). Der Spiegel, 33/1955, 16-26.

Von Beyme, K. (1996). Deutsche Identität zwischen Nationalismus und Verfassungspatriotismus. In M. Hettling, \& P. Nolte (Eds.), Nation und Gesellschaft in Deutschland (pp. 81-99). Munich: Beck.

Von Beyme, K. (1999). Shifting national identities: The case of German history. National Identities, 1(1), 39-52.

Walser, M. (1993). Deutsche Sorgen. Der Spiegel, 26, 40-47.

Wehler, H.-U. (1994). Die Gefährdung des Sozialstaates durch Nationalismus und Fremdenfeindlichkeit. In J. Kocka, H.-J. Puhle, \& K. Tenfelde (Eds.), Von der Arbeiterbewegung zum modernen Sozialstaat (pp. 778-789). Munich: K. G. Saur.

Wehler, H.-U. (2001). Nationalismus. Munich: Beck.

Werden den US den Titel abluchsen. Deutsche Wirtschaft will Vize-Exportweltmeister werden. (2013, 17 April). Focus. Retrieved from https://www.focus.de/finanzen/news/werden-den-usa-den-titelabluchsen-deutsche-wirtschaft-will-vize-exportweltmeister-werden_aid_962262.html

Winkler, H. A. (2000). Der lange Weg nach Westen II. Munich: Beck.

Ziem, A. (2010a). Fußball als Interdiskurs: Lexikalische Felder, konzeptuelle Metaphern und Domänenmischung. Zeitschrift für Semiotik, 32(3-4), 305-328.

Ziem, A. (2010b). Fußball als Zeichenprozess: Ansätze zu seiner diskursanalytischen Beschreibung. Zeitschrift für Semiotik, 32(3-4), 227-240. 